Patricia Martínez García de Leaniz

martinezrp@unican.es

University of Cantabria

Faculty of Economics

Avenida de los Castros s/n

39005 - Santander (Cantabria, SPAIN)

Phone number : +0034.942.20.16.61

\author{
Andrea Pérez Ruiz \\ perezran@unican.es \\ University of Cantabria \\ Faculty of Economics \\ Avenida de los Castros s/n \\ 39005 - Santander (Cantabria, SPAIN) \\ Phone number : +0034.942.20.16.61 \\ Ignacio Rodríguez del Bosque Rodríguez \\ rbosquei@unican.es \\ University of Cantabria \\ Faculty of Economics \\ Avenida de los Castros s/n \\ 39005 - Santander (Cantabria, SPAIN) \\ Phone number : +0034.942 .20 .16 .61$
}




\title{
Measuring Corporate Social Responsibility in tourism: Development and validation of an efficient measurement scale in the hospitality industry
}

\begin{abstract}
This article aims at developing an efficient measurement scale for corporate social responsibility in the tourism industry, given the contextual character that is recognized in the practice of this construct. Indicators were generated on the basis of a literature review and qualitative research. To assess the reliability and validity, first and second-order confirmatory factor analysis were carried out. Results show a multidimensional structure of this construct, including economic, social and environmental issues. This study contributes to the advancement of knowledge in the field of social responsibility through its practical application regarding concepts of sustainable development which have mainly been theoretical.
\end{abstract}

Key Words: Corporate Social Responsibility, scale development, sustainable development, tourism sector, hospitality industry

\section{1. - Introduction}

An increasingly important aspect of corporate management in recent decades has been the incorporation of corporate social responsibility (CSR), a construct that emphasises the obligation of companies to integrate social and environmental parameters into their modus operandi and their long-term development policies (Persais, 2002). This phenomenon can be explained because of an increased pressure on certain social and economic factors, the greater need for transparency in organizations, and as a reaction to social and environmental disasters (Swaen \& Chumpitaz, 2008). Although CSR is one of the most prominent themes in the marketing literature, it is difficult to provide a precise and comprehensive definition of the term. Walker, Heere, Parent and Drane (2010) illustrate that the meaning of CSR differs 
among different stakeholders. The measurement of CSR activities is an additional challenge. Despite the publication of several methods to measure socially responsible activities, as reputation indices, databases, indicators, content analysis of publications or surveys of organizational members, almost all of them have some limitations (Aupperle, Carroll \& Hatfield, 1985; Maignan \& Ferrell, 2000; Turker, 2009). These limitations will be mentioned in detail in the literature review section of this article. Therefore, the methodology must be adjusted to provide a more complete understanding of the current state of CSR.

The purpose of the present study is to address this gap in knowledge by providing a new scale for measuring customers' perception regarding companies' participation in socially responsible activities in the tourism industry in an attempt to evaluate the perception of customers regarding CSR performance of organizations in the hospitality sector based on the theory of sustainable development. According to researchers, these perceptions reflect the activities of the company in relation to what the different target audiences consider to be its social obligations (Berens, van Riel \& van Rekom, 2007; Brown \& Dacin, 1997; Sen \& Bhattacharya, 2001). The theoretical perspective of sustainable development has been widely applied in the field of tourism (Gladwin \& Kennelly, 1995; Henderson, 2007; Kakabadse, Rozuel \& Lee-Davies, 2005; Wheeler, Colbert \& Freeman, 2003).

There are several justifications for our choice of the tourism sector in general and the hotel segment in particular. First, the tourism sector is one of the main service industries worldwide. In the year 2000, businesses related to the tourism sector generated approximately $\$ 2$ trillion and provided employment for approximately $15 \%$ of the world's economically active population (Faulkner, Mascardo \& Laws, 2000). The share of the developing countries' international tourism had also increased from approximately $10 \%$ in the 1970 s to around 30 $\%$ (World Travel \& Tourism Council, 2000). These developments encouraged the World 
Tourism Organization (WTO) to forecast annual growth rates of $4.3 \%$ during the next two decades, and they expect the figure to rise to 1,600 million international arrivals by the year 2020 (WTO, 1997). In Spain this sector contributes $10.7 \%$ to the GDP, generating more than 2.5 million direct jobs and representing an income of $€ 3,861$ million in 2010 (Tourism Studies Institute, 2011). Furthermore, Spain is the fourth most visited country in the world after France, the United States and China with 53 million visitors (World Travel Organization, 2011).

Secondly, the hotel segment has been significantly transformed in recent years as a result of the global economic crisis, which has caused a severe recession in the hospitality sector (Cizmar \& Vlahov, 2010). All regions worldwide have been affected by the crisis, and in 2009 and 2010 Europe suffered one of the world's largest drops in income (-6\%) and international visitors (-4\%) compared with the previous year (World Tourism Organisation, 2011). Surveys in 2010, such as the "DLA Piper's 2010 Europe Hospitality Outlook", suggest a slow recovery in the hospitality industry. Of the experts surveyed, $40 \%$ do not expect this sector to recover in the coming years, and more than half of the respondents (68\%) are pessimistic about the prospects for the hotel industry (DLA Piper, 2010).

However, in a market still struggling to regain its balance, an optimistic sentiment has begun to gain momentum. Of the businesses surveyed, $84 \%$ think that the importance of CSR will be the same or greater in the coming years (Forética, 2011), and $23 \%$ of experts believe that practices related to CSR will guide consumer decisions in the long term (DLA Piper, 2010). Thus, businesses that demonstrate sensitivity to the environment, both social and natural, will have greater success (Bigné, Font \& Andreu, 2000).

Therefore, companies must seek positions that are new, unique and differentiated from the competition. In this sense, CSR has become a highly effective attribute for a strategy of 
differentiation and positioning (Drumwright, 1996; Du, Bhatthacharya \& Sen, 2007). The increased sensitivity of customers to social and environmental problems lead them to demand the protection of the cultural and environmental heritage of the places they have visited (Bigné et al., 2000). This, in turn, encourages tourism companies, including hospitality businesses, to try to offer unique and varied experiences to consumers. In this sense many international initiatives show the growing importance of CSR in the tourism and hotel industry. For instance, Agenda 21 set international guidelines relative to sustainable tourism and was created by the World Travel and Tourism Council (WTTC), the World Tourism Organization (WTO), and the Earth Council. In Europe the Initiative for Improving CSR in the Hospitality Sector has been established. As far as this initiative is concerned, the European Federation of Food and Agriculture and Tourism Trade Unions and Hotels, Restaurants and Cafés in Europe drafted compliance parameters concerning equal opportunity, non-discrimination, working conditions, fair pay, vocational training and lifelong learning, health and safety, and the relationship between employers and employees at all levels. Other initiatives, such as that of Green Hotels, focus on programs that are designed to save water, save energy and reduce solid waste (Green Hotels Association, 2005) and it is an initiative of the Green Hotels Association. The Green Hotelier, a publication of the International Tourism Partnership, is a magazine whose readership cares about environmentally and socially responsible hotel behavior as focused upon positive sustainable travel and tourism development (Green Hotelier, 2005).

Finally, it should be noted that the authors conducted the study on the tourism sector, specifically in the hotel segment. With regard to this, it must be stated that the tourism sector has some special particularities because it is possible to identify several subsectors with different characteristics and problems, such as transportation, travel or accommodation (Ayuso \& Fulana, 2002) that could potentially distort the results of this research if 
presented together. This is the main reason why we decided to focus on a single tourism subsector — the lodging sector- and more precisely in the Spanish hotel sector.

Therefore, this study contributes to the literature by providing a new, valid, and reliable CSR measurement tool. Based on the conceptual framework proposed, this measurement tool reflects the CSR-related dimensions of tourist services as perceived by the customers. This paper is divided into three main sections. The first section presents the conceptual framework that forms the structural basis for the study. The second section presents the methodology, emphasising the design of the measurement scale. Finally, a brief discussion of the results and future lines of research arising from this study are included.

\section{2. - Literature review}

\section{1. - Conceptual bases: the definition of CSR and the role of context}

Although some publications present CSR as a new construct (D'Humières \& Chauveau, 2001), the idea that companies must manage their social and environmental obligations has its roots in a much older debate (Dejean \& Gond, 2004). In fact, the role of business in society has been a matter of debate since the middle of the last century (Turker, 2009). Various studies in economic and organizational theory (Davis, 1973; Keim, 1978; Shaw \& Post, 1993) have reviewed the role of business in society, and all of them agree that the purpose of business should be broadened beyond only economic benefits (Friedman, 1970) and that a social dimension should be incorporated into corporate performance.

Despite the fact that CSR is a prominent concept in the literature, it is difficult to formulate a precise and comprehensive definition of the term. As Votaw (1972) and more recent authors argue (Heere, Parent \& Dan Drane, 2010), CSR has a meaning, but its meaning is not the same for everyone. As a result, the literature regarding this concept has occasionally been 
described as lacking cohesion, consensus, and theoretical maturity, thus resulting in great confusion and ambiguity (Carroll, 1999; Godfrey, 2005). One of the main reasons given is that the meaning of CSR varies depending on the perceptions of the stakeholders involved and on the business sector under study (Campbell, 2007; Carroll, 1979; Decker, 2004; Whitehouse, 2006).

Howard Bowen (1953), one of the first scholars to define this concept, defined the social responsibility of businessmen as the obligation to pursue policies, make decisions, and follow lines of action that are desirable in terms of the objectives and values of society. In more recent years, many new definitions have emerged, highlighting the contextual nature of CSR in the absence of a universal definition of this concept (Whitehouse, 2006). In this sense, many definitions of CSR are based on two fundamental ideas. The first is that companies have responsibilities beyond their profit-making activities and mere legal liability (Carroll, 1979; García de los Salmones, Herrero \& Rodríguez del Bosque, 2005; Maignan, 2001; Maignan \& Ferrell, 2000; Maignan, Ferrell \& Hult, 1999). The second is that these responsibilities apply not only to shareholders but to a broader group of stakeholders (Freeman, 1984; Freeman, 2000; Swaen \& Chumpitaz, 2008; Wheeler et al., 2003). These elements are apparent in the European Commission's (2001) definition of CSR as the voluntary integration by companies of social and environmental concerns in their business operations and their relationships with their stakeholders, including shareholders, NGOs, suppliers, customers, and authorities. Along this line is the definition proposed by Panwar, Rinne, Hansen and Juslin (2006), who define this construct as a strategic and proactive way of doing business in a specific context with a synergistic philosophy. This concept of CSR emphasises the need for firms to design their strategies with particular attention to balancing economic, social, and environmental aspects. 
Most theoretical research on this concept has focused on investigating the relationship between CSR and corporate financial performance (Rowley \& Berman, 2000; Walsh, Weber \& Margolis, 2003). Other authors have studied the degree to which a business applies CSR (Clarkson, 1995; Joyner \& Payne, 2002; Maignan \& Ferrell, 2000). More recently, several studies have attempted to measure the relationship between social performance and employer attractiveness (Backhaus, Stone \& Heiner, 2002; Greening \& Turban, 2000), the orientation toward the social behavior of students of different nationalities (Bigné, Andreu, Chumpitaz \& Swaen, 2005; Mukherji \& Mukherji, 2002), and the influence of the concept on consumer behavior (Brown \& Dacin, 1997; García de los Salmones et al., 2005; Maignan, 2001; Maignan et al., 1999). However, although CSR is a term commonly used by professionals, methods to formally measure CSR have not been developed among academics (Maignan \& Ferrell, 2000). Therefore, efforts to develop measurement scales must be intensified because, as Carroll (2000) argues, the real question is whether valid and reliable measures can be developed.

To obtain a deeper understanding of this issue, it is vital to consider the role of context in the practical articulation of CSR. As Sethi (1975) explains, an evaluation of the social performance of a company that ignores its cultural and socio-political environment is fraught with conceptual and methodological hazards. A basic assumption of CSR is that companies must adapt their behavior to societal expectations (Sethi 1975; Ward, Borregaard \& Kapelus, 2002). Complications arise when these expectations vary, depending on the context in which a firm operates. Contextual features refer to the specific geographic, social, cultural, and economic policies of the places in which companies carry out their activities (Vidal \& Kozak, 2008). These features play an important role in determining the responsibilities of businesses and, consequently, in their responses to issues of CSR (European Commission, 2002; Strand, 1983; Ward et al., 2002). Furthermore, as we have discussed previously, the social and 
environmental aspects that companies choose to address vary depending on the sector in which the companies operate (Campbell, 2007; Carroll, 1979; Decker, 2004; Whitehouse, 2006). Because the way companies define, design, and implement their CSR policies depends heavily on the contextual features of the realm in which they operate, this paper suggests a new scale for measuring CSR in the tourism sector based on the theoretical framework proposed by Panapanaan, Linnanen, Karvonen and Phan (2003) and Panwar et al. (2006). This component is based on the theory of sustainable development, as this is one of the theoretical perspectives with the greatest relevance to the field of tourism (Gladwin \& Kennelly, 1995; Henderson, 2007; Kakabadse et al., 2005; Wheeler et al., 2003).

\section{2. - Academic proposals for measuring corporate social responsibility}

A variety of measurement methodologies can be found in the academic literature. However, as Wolfe and Aupperle argue (1991), there is no single way to measure CSR activities. In fact, CSR has strong contextual characteristics, so that the concept and its component dimensions are determined by the particular characteristics of the companies in each industry and the context in which they operate (Campbell, 2007; Carroll, 1979; Decker, 2004; Whitehouse, 2006).

Maignan and Ferrell (2000) categorised the existing alternative methods into three main approaches: (1) expert assessments, (2) single or multiple indicators, and (3) surveys of management. The first category of empirical investigations has evaluated corporate social performance based on information provided either by industry experts or by experts in the business or society area. In this sense, several studies have measured corporate social responsibility with reputation index and databases, which requires executives to assess the extent to which specific companies operating in their own sector behave responsibly towards the environment and the community. 
Regarding the second category of investigations, some researchers have used more objective indicators in order to avoid the subjectivity inherent in evaluations of experts. For example, Bragdon and Marlin (1979) used a pollution control index published by the Council of Economic priorities. Other researchers have considered corporate criminality as an indicator of CSR (Baucus \& Baucus, 1997; Davidson \& Worrell, 1990). An increasing number of studies incorporate several types of measures (Stanwick \& Stanwick, 1998; Turban \& Greening, 1996). For example, Griffin and Mahon (1997) combined four estimates of corporate social responsibility: the Fortune reputation index, the KLD index, the Toxic Release Inventory (TRI), and the rankings provided in the Directory of Corporate Philanthropy.

As far as the third category is concerned, a number of scholars such as Aupperle et al. (1985) asked respondents to express their level of agreement or disagreement with twenty statements about social responsibilities of businesses. These authors then argued that the answers were reflective of the commitment to corporate social responsibility shown by the organizations employing the respondents. Other surveys conducted to date have also focused on perceptions of CSR activities and not on corporate behaviors (Pinkston \& Carroll, 1994; Singhapakdi, Kraft, Vitell \& Rallapalli, 1995).

Based on Turker (2009) and expanding this classification, the following approaches are considered feasible for measuring CSR: reputation indices, databases, single and multiple indicators, content analyses of publications, and measurement frameworks at the individual and organizational levels (Table 1). The aim of this paper is not to describe each of these approaches in detail but to focus on those aspects that are relevant to the present study, in terms of their main limitations.

TABLE 1. Existing methods for measuring CSR 
Reputation indices and databases are among the methods used to assess socially responsible activities. The Fortune reputation index; the index developed by Kinder, Lydenberg and Domini (KLD); and the Canadian Social Investment Database (CSID) are examples. A limitation of the indices is that the utilized aspects are not based on theoretical arguments (Maignan \& Ferrell, 2000). Similarly, the databases only consolidate information from firms in a specific market; thus, they have a narrow evaluation range (Turker, 2008).

As mentioned before, the third proposed alternative method is to use both one-dimensional indicators as the pollution control rate (Bragdon \& Marlin, 1979) or the rate of corporate crime (Baucus \& Baucus, 1997; Davidson \& Worrell, 1990) and multidimensional indicators (Griffin \& Mahon, 1997; Stanwick \& Stanwick, 1998; Turban \& Greening, 1996). However, even overcoming the limitation of the first group in terms of unidimensionality and using the second set of indicators, this approach still presents a serious limitation when encompassing the entire structure of CSR (Maignan \& Ferrell, 2000); as these authors suggest, the indicators used may not be representative of the same underlying construct.

Another method used in the literature is the content analysis of publications. Particularly in recent years, CSR information has become more accessible as a result of the growing attention that companies give to the disclosure of their socially responsible practices (Gray, Kouhyar \& Lavers, 1995). However, the information in a corporate report may be different from the activities that were actually performed (McGuire, Sundgren \& Schneeweis, 1988). Therefore, the reliability of the companies may be an important limitation. Another approach to the measurement of CSR is to interview members of the organisation. The main limitation of this type of research is that it assesses the commitment of individual directors, and, therefore, it is not possible to estimate the socially responsible practices adopted by 
companies as a whole. Other surveys have focused on managers' perceptions of CSR and not on business behavior (Pinkston \& Carroll, 1994; Singhapakdi et al., 1995).

The sixth method, which is the most relevant to the present research, is based on the use of scales that measure the perception of CSR activities by individuals. Whereas the above methods attempt to measure the actual performance of CSR, this method measures the perceptions that stakeholders have of the concept. In this research, we focus on measuring customer perception as an interest group. This method seems the most appropriate because the other approaches include aspects that may not be evaluated by the consumer because it is difficult for consumers to acquire and store information about CSR (Mohr, Webb \& Harris, 2001), mainly due to the multidimensional nature of the concept (Maignan \& Ferrell, 2001). Among the most outstanding academic developments in this group are models of corporate associations (Brown \& Dacin, 1997), the pyramid developed by Carroll (1979, 1999), models focused on the theory of interest groups (Clarkson, 1995; Decker, 2004; Maignan et al., 1999; Turker, 2009), and those based on the theory of sustainable development (Bigné et al., 2005; Panapanaan et al., 2003; Panwar et al., 2006; Van Marrewijk, 2003).The models described almost entirely coincide in highlighting the perception of CSR as a multidimensional construct while differing significantly in both the number of dimensions and the component factors.

Among the academic developments that pose CSR as a multidimensional construct, the work that has become increasingly accepted and has been used by several authors, both theoretically and empirically (García de los Salmones et al., 2005; Maignan et al., 1999; Maignan, 2001; Maignan \& Ferrell, 2000), has been that proposed by Carroll in 1979 and revised in 1991 and 1999. Carroll argues that CSR includes society's economic, legal, ethical, and philanthropic or voluntary expectations of organisations at a given point in 
time. According to this model, there are four interrelated dimensions of CSR. The economic dimension refers to society's expectation that companies be profitable and that they are rewarded for their efficiency and effectiveness in the production and sale of goods and services. The legal dimension is understood as the societal expectation that businesses achieve their financial goals within the confines of the legal framework. The ethical dimension refers to society's expectation that business practices meet certain ethical standards. Finally, the discretionary or philanthropic dimension relates to society's expectations that companies will voluntarily involve themselves in roles to address social needs.

Carroll's model, as well as other less established frameworks, such as the corporate associations described by Brown and Dacin (1997), have not been subjected to scrutiny by stakeholders and consumers (Maignan \& Ferrell, 2003), and the study of these models has usually been based on definitions provided by company directors (Aupperle et al., 1985; Swaen, Chumpitaz, Bigné \& Andreu, 2003). Thus, little is known about consumers' perceptions of CSR (Bigné et al., 2005; Bigné, Andreu, Chumpitaz \& Swaen, 2006; García de los Salmones et al., 2005; Maignan \& Ferrell, 2003; Swaen et al., 2003) or to what extent this framework and its dimensions properly reflect the perceptions of this group of stakeholders. Thus, the relevance of Carroll's work may remain in doubt (Maignan, 2001; Maignan \& Ferrell, 2003).

A second approach is based on the postulates of the theory of interest groups (Freeman, 1984). According to this proposal, the components of CSR should be classified according to those interest groups that benefit the most from them and are the main target audience of each action. Following this approach, the literature has identified various dimensions of CSR: consumers, employees, shareholders, society in general, the environment, and the market, 
among others (Decker, 2004; Maignan et al., 1999; Turker, 2008). This model is not without its critics, and there are studies that indicate its limitations (Turker, 2008). The main limitation described in these studies is that the research conducted in this area has taken into account only a limited number of target audiences and not all of the stakeholders of the companies.

A third perspective on the measurement of CSR proposes a focus on sustainable development (Bigné et al., 2005; Panapanaan et al., 2003; Panwar et al., 2006; Van Marrewijk, 2003). The special relevance of the environmental dimension makes this approach the most suitable for the present study because tourism is one of the sectors with the greatest impact on the physical environment (Jamrozy, 2007; Timur \& Getz, 2009). Furthermore, this approach has contributed to improve the understanding and clarity of CSR (Truscott, Bartlett \& Tywoniak, 2009); in addition to being used both for the management of this concept and at the operational level (Adams \& Zutshi, 2004). From this perspective, the concept of CSR is reinforced as a multidimensional construct that equally emphasises economic, social, and environmental aspects. Several authors support this approach, particularly in relation to tourism (Henderson, 2007; Kakabadse et al., 2005). This model is, a priori, suitable for this investigation because it can lead to improved management and operational objectives (Kakabadse et al., 2005).

The dimensions of CSR can be identified from the conceptual framework provided by the theoretical models proposed by Panapanaan et al. (2003) and Panwar et al. (2006). These authors conceptualise CSR based on sustainable development, establishing that corporate responsibility is a multidimensional construct consisting of economic, social, and environmental dimensions. The World Tourism Organisation (2004) emphasises each of these facets. The economic dimension is based on ensuring viable economic activities in the 
long term so that all stakeholders receive appropriately distributed socio-economic benefits. The social dimension refers to a respect for the cultural authenticity of host communities, the preservation of their architectural and living cultural assets and traditional values, and a contribution to intercultural understanding and tolerance. The environmental dimension refers to the optimal use of environmental resources, which is an essential element of tourism development, protecting essential ecological processes and helping to conserve natural resources and biodiversity. In summary, a review of the literature reveals the existence of different methods for measuring socially responsible actions. Although all of these methods have contributed to the literature on CSR, they all have limitations. More importantly, the different perspectives on the concept of sustainable development have mainly been developed in a theoretical manner (Panapanaan et al., 2003; Panwar et al., 2006; Van Marrewijk, 2003); thus, there is a need to establish a new measurement methodology for CSR that addresses the conceptual framework proposed.

\section{3. - Research methodology}

\subsection{Sampling and data collection}

The analysis and evaluation of the socially responsible actions of companies was performed through a quantitative study. In particular, personal surveys of hotel customers over 18 years of age were conducted in Spain according to a structured questionnaire developed by the researchers. Respondents were asked to assess national hotels where they had spent their last holidays in the last year. Interviews were carried out in the respondents' homes to ensure their comfort and make sure that they took time to answer the questions calmly and thoughtfully. The data collection was developed in collaboration with university students of the University of Cantabria coursing their last academic year. Specifically, the total number of students amounted to 258. To design the research sample, a non-probability sampling 
procedure was chosen (Trespalacios, Vázquez \& Bello, 2005). Specifically, a convenience sample was used, as the researchers did not have access to a census of hotel clients over the age of 18 in the Autonomous Community of Cantabria (Spain), and it was not possible to determine the probability of any particular element of the population being chosen for the sample (Trespalacios et al., 2005).

Thus, to ensure greater representation of the data, a multistage sampling by quotas was made by characterising the population according to two criteria relevant to the investigation: the sex and the age of the respondent, which is included in the Census Bureau (2010). Fieldwork was conducted in April 2011. From the target sample of 2016 questionnaires, only 1924 completed questionnaires were completed, 92 were discarded as incomplete. Hence, the final response rate was $95.43 \%$. Respondents were asked to evaluate their perception regarding the CSR performance of hotel companies in Spain. Table 2 displays the main characteristics of the research. The socio-demographic profile of respondents is included in Table 3.

TABLE 2. Quantitative research technical record

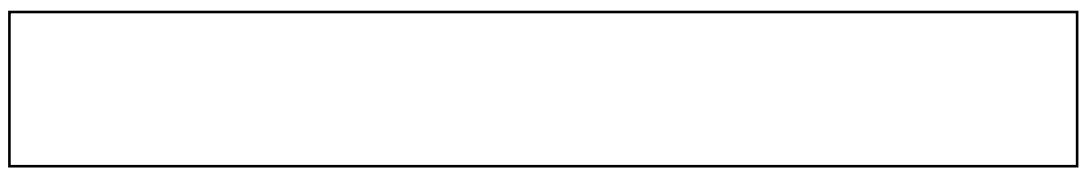

TABLE 3. Sample profile

\section{2. - Design of the measurement scale}

The authors followed Churchill's (1979) methodological proposal, based on a standard procedure for developing instrument measures, in order to design a new multi-item scale that 
includes items previously used in marketing literature regarding CSR. Previous researchers have used this procedure before (Hung \& Petrick, 2010; Turker, 2009).

The eight steps of measurement development recommended by Churchill (1979) are listed in the first two columns of Table 4. While steps one to four address concerns of content validity, dimensionality, and internal consistency, steps five to eight address the concerns for reliability, criterion validity, and construct validity. Churchill (1979) suggested that researchers can use these procedures with certain flexibilities and the recommended techniques can be replaced with other alternatives. The alternatives used in the current study included 1) incorporating a panel of experts to generate samples of items and 2) assessing reliability and validity of measurement scales with composite reliability, convergent validity and discriminant validity (Anderson \& Gerbing, 1988; Hung \& Petrick, 2010; Steenkamp \& Van Trijp, 1991; Turker, 2009).

\section{Table 4. Procedure for developing instrument measures}

First, the multidimensionality of the scale was conceptualized based on both a literature review and a qualitative exploratory research based on a panel of experts which was comprised of eight academics and experts in the tourism area. With regard to this, the experts participating in the panel are summarized in the following table:

Table 5. Experts participating in the panel 
After this first step, three domains were identified as relevant for the CSR of a hotel company: Economy, society and environment. These dimensions match up with those defined theoretically by the sustainable development theory (Bigné et al., 2005; Panapanaan et al., 2003; Panwar et al., 2006; Van Marrewijk, 2003). In a second phase, items in each dimension were generated through a literature review. This phase was based on a multiattribute scale established by Bigné et al. (2005). This scale, however, has not been previously confirmed by first- or second-order factor analysis, a task which is undertaken in this research.

To test the adequacy of this new CSR measurement scale, a quantitative study based on personal surveys of Spanish customers of hotel companies were designed. Respondents were asked to rate their perceptions of what the companies actually do about CSR rather than what the company should do. Initially, the measurement scale included eighteen items. The first five items related to activities aimed at the economic dimension of CSR. The next six items related to the social dimension of CSR. Items 12 to 18 related to the environmental dimension of CSR. All of the items were measured using a seven-point Likert scale, in which a score of 1 indicates "strongly disagree with the statement", and a score of 7 signifies "total agreement with the statement".

We first conducted an exploratory factor analysis. This empirically verifies the existence of the three factors proposed in this study: the economic domain of CSR, the social domain and the environmental domain. However, the analysis conducted revealed that one of the items initially proposed for the measurement scale needed to be eliminated. Specifically, we removed the factor related to job creation in the economic dimension for which the factor loading was less than 0.5 (Steenkamp \& Van Trijp, 1991), making it inappropriate for inclusion in the measurement scale. The final items are listed in Table 8. 


\section{4. - Discussions}

\section{1. - Validation of the measurement scale}

As Churchill (1979) and Hung and Petrick (2010) propose, the first step in the validation of a measurement scale is the development of a confirmatory factor analysis. To evaluate the psychometric properties of reliability and validity for the proposed measurement scale, firstand second-order confirmatory factor analyses were performed according to the maximum robust likelihood estimation procedure, using the statistical software program EQS 6.1 (Bentler, 1995). The reliability of the measurement scale was evaluated by Cronbach's $\alpha$ coefficients (Cronbach, 1951) and by an Average Variance Extracted (AVE) (Hair, Anderson, Tatham \& Black, 2010). The values of these statistics exceed the minimum recommended values of 0.7 and 0.5 , respectively (Hair et al., 2010), confirming the internal reliability of the proposed construct. In addition, all items are significant at a confidence level of $95 \%$, and standardised lambda coefficients are above 0.5 (Steenkamp \& Van Trijp, 1991), confirming the convergent validity of the model. To test the discriminant validity, we followed the procedure described by Anderson and Gerbing (1988), in which estimates of the confidence intervals for the correlation of the constructs are made and compared with the unit. In neither case do the intervals contain the value 1.

In order for the measurement to be generalized, criterion validity, which accesses external validity of a measurement scale, must be examined via correlations coefficients (Kline, 2005). Each dimension was represented by a composite score computed by taking the average scores of all items in this specific CSR dimension. All correlations are statistically significant at 0.01 level. The positive Pearson correlation coefficients $(r=0.854$ for the first correlation and 0,701 for the last correlation) indicate positive relationships between the CSR 
dimensions. Thus the criterion validity of the scale was acceptable. Thus, the proposed measurement model is acceptable (Table 6).

Table 6. Discriminant validity

Finally, the goodness of fit of the analysis was verified with the Satorra-Bentler $\chi^{2}\left(\mathrm{~S}-\mathrm{B} \chi^{2}\right)(\mathrm{p}$ $<0.05$ ) and the comparative fit indices (Ullman, 1996) NFI and NNFI (Bentler \& Bonnett, 1980), IFC (Bentler, 1988), and IFI (Bollen, 1989), which are the most common measures for confirmatory tests (Uriel \& Aldás, 2005). All values were greater than 0.9 (Bentler, 1992), indicating that the model provides a good fit. Moreover, although the S-B $\chi^{2}$ statistic is significant for a significance level of $\mathrm{p}<0.05$, it cannot be considered a reliable indicator of the goodness of fit of the confirmatory analysis because of its sensitivity in samples exceeding 200 units (Bollen, 1989).

TABLE 7. First-order confirmatory factor analysis of the dimensions of corporate social responsibility

Finally, with the two first-order factor analyses carried out, exploratory and confirmatory must be completed through the development of a second-order confirmatory factor analysis to gain a better understanding of the concept under study . CSR is seen as a second-order factor generated from the relationship between the lower-order factors of economy, society, and environment. Figure 1 shows the final estimates of the second-order model. The goodness-of- 
fit indices (NFI, NNFI, CFI, and IFI) exceed the recommended value of 0.90 , and the RMSEA (Root Mean Square Error of Approximation) is very close to the value of 0.08. Therefore, it can be argued that the adjustment of the second-order model is acceptable. The estimated coefficients for the three CSR factors are all positive and significant for a confidence level of $95 \%$. Consequently, these factors accurately represent the underlying concept. The first important result is that tourism service customers perceive CSR as a combination of corporate actions in the economic, social, and environmental spheres. However, the economic dimension appears to have less weight within the construct of CSR based on its loading factor. The final CSR measurement scale with all the items is included in table 8 .

FIGURE 1.Second-order confirmatory factor analysis of the dimensions of corporate social responsibility

TABLE 8. Final CSR measurement scale

\section{2.-Descriptive statistics}

The development and testing of the CSR measurement scale elaborated in this research enables the evaluation of socially responsible actions by the hotels. In a first approximation, and without reference to the dimensions of CSR, the most highly rated aspects were the following: ensuring the survival of the company and its success in the long term (meanCSR4 
$=5.80$ ), achieving long-term success (meanCSR2 $=5.69$ ), obtaining the greatest possible profits (meanCSR1 = 5.67), and improving the financial performance of the company (meanCSR3 $=5.57$ ). In turn, the aspects rated lowest by the interviewees were the following: the company's role in society beyond the mere generation of profits (meanCSR7 $=3.78$ ) and helping to solve social problems and conduct annual environmental audits (meanCSR16 = 3.69). Factors such as providing training and promotion opportunities for employees $($ meanCSR9 $=4.39)$ and reducing the consumption of natural resources $($ meanCSR12 $=4.18)$ occupied a middle ground in customer perceptions of tourism services.

TABLE 9. Assessment of the performance of the hotels analyzed in each factor of the CSR measurement scale

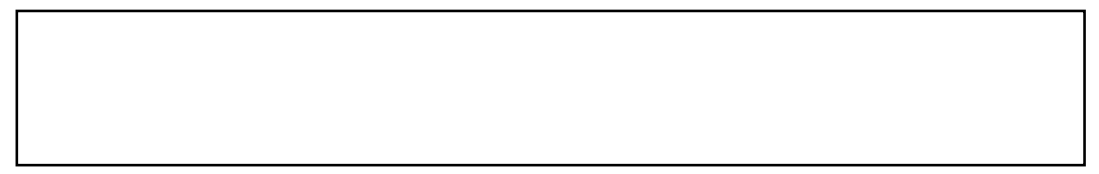

A means test of each of the dimensions of the concept of CSR was performed to ensure that the above differences among the dimensions were significant. The analysis shows that there are significant differences in the ratings that hotel customers attach to each of the dimensions (Table 10).

TABLE 10. Means test of the ratings of the CSR dimensions 
Comparing the ratings for each of the dimensions shows that customers give a higher positive rating to corporate actions that ensure sustainable economic practices over the long term. The perception of corporate performance with regard to social and environmental factors is significantly lower. Following the proposed dimensioning in this paper, the dimensions of CSR with the highest ratings are the economic $\left(\right.$ mean $\left._{\text {Economic }}=5.68\right)$ and social dimensions $\left(\right.$ mean $\left._{\text {Social }}=4.11\right)$, and the lowest-rated dimension is the environmental $\left(\right.$ mean $_{\text {Environmental }}=$ 4.03) dimension, indicating an area of significant opportunity for hotel management.

The aspect with the lowest score in the economic dimension relates to improving the economic performance of the company $\left(\right.$ mean $\left._{\operatorname{CSR} 3}=5.57\right)$, and the highest-rated aspect is the assurance of the organisation's long-term survival and success ( mean $\left._{\operatorname{CSR} 4}=5.80\right)$. Similarly, the lowest-ranked aspect in the social dimension is helping to solve social problems $\left(\right.$ mean $\left._{\mathrm{CSR} 10}=3.74\right)$, and the aspect with the highest score is providing fair treatment for employees without discrimination or abuse and regardless of gender, race, origin, or religion $\left(\right.$ mean $\left._{\operatorname{CSR} 8}=4.68\right)$. In the environmental dimension, conducting annual environmental audits is the aspect with the lowest score (mean $\operatorname{CSR}_{16}=3.69$ ), and recycling is the aspect with the highest average score $\left(\right.$ mean $\left._{\operatorname{CSR} 13}=4.48\right)$. Thus, each of the aspects with the lowest score in each of the CSR dimensions highlights important areas of opportunity for the managers of the hotels studied.

\section{5. - Conclusions}

A strong current trend is the use of sustainable development theory to propose a new dimensioning of CSR composed of not only economic but also social and environmental aspects (Bigné et al., 2005; Panapanan et al., 2003; Panwar et al., 2006; Van Marrewijk, 2003). This line of research is relatively recent, and few studies have attempted to provide 
solid and reliable scales for measuring this concept in the manner proposed by this research. Furthermore, as argued in the literature, the application of the principles of CSR is highly conditioned by the contextual features of the sectors to which it is applied (Campbell, 2007; Carroll, 1979; Decker, 2004; Whitehouse, 2006); thus, the design of measurement scales adjusted to different environments is essential for the proper understanding of the state of CSR today. Given the perceived limitations of previous measurement scales, the aim of this work was to develop a new tool for measuring CSR in the tourism sector based on the perceptions of hotel clients.Following Churchill's (1979) methodological proposal, this study incorporated both qualitative and quantitative methods to develop a measurement scale. A panel of experts was set up firstly to generate a sample of items for further development of a measurement scale. After this first step, three domains were identified as relevant for the CSR of a hotel company: economy, society and environment. These dimensions match up with those defined theoretically by the sustainable development theory. In order to test the adequacy of this new CSR measurement scale, a quantitative study based on personal surveys of Spanish customers of hotel companies was designed. A total of 1924 questionnaires were collected.

The first interesting result of this study is the confirmation of the multidimensional nature of CSR, which is consistent with the findings of previous research (Bigné et al., 2005; Decker, 2004; García de los Salmones et al., 2005; García de los Salmones et al., 2007; Maignan, 2001; Maignan et al., 1999; Singh et al., 2008), regardless of the fact that the theoretical frameworks used in some of these studies are different from that used in the present research. Secondly, we show that, from a consumer's perspective, CSR is perceived as a set of economic, social, and environmental attributes. In this sense, the acceptance of an economic dimension of CSR by tourism consumers supports previous findings (Bigné et al., 2005; Bigné et al., 2006; Maignan, 2001; Maignan \& Ferrell, 2003). These results provide 
support for the exploratory work of Bigné et al. (2005) and Bigné et al. (2006), which contrasted consumers' perceptions of CSR activities in four Ibero-American countries Argentina, Chile, Spain and Portugal - using a sustainable development approach, particularly in the social and environmental dimensions. Thus, the theoretical proposal of sustainable development is validated in the present study, as the customer perception of socially responsible tourist service companies includes economic, social, and environmental aspects.

This study contributes to the advancement of knowledge in the field of CSR through its practical application of concepts of sustainable development that have mainly been theoretical to date (Panapanaan et al., 2003; Panwar et al., 2006; Van Marrewijk, 2003). In addition, the specific perceptions of different stakeholders of the responsibilities that must be assumed by a company have rarely been discussed in academic research. Thirdly, the consumer evaluations of tourism services with respect to each of the dimensions of CSR in which tourism-related businesses are involved represent an important finding. The most highly rated factor, above the social and environmental dimensions, is sustainable economic practices over the long term. These results are consistent with the idea that the main business activity of any company that emphasises profit is improved economic performance and longterm success and survival. Context is important in the practice of CSR (Campbell, 2007; Decker, 2004; Kakabadse et al., 2005; Whitehouse, 2006). Because the tourism industry is one of the most vulnerable to economic crises (Cizmar \& Vlahov, 2010), consumer perceptions may be compounded by the current economic situation, which has had effects on the national economy (job elimination, wage cuts, etc.) and may lead to a higher consumer rating of this dimension as a priority within the CSR policies of companies. The socioeconomic context in which CSR is implemented can substantially affect certain CSR variables and hamper the ability of a company to provide sufficient information for its 
stakeholders to assess corporate performance on social responsibility (Forética, 2011; Whitehouse, 2006).

Furthermore, in view of the assessment of the social and environmental dimensions, our findings highlight several areas of opportunity for improvement with important implications for managers of tourism organisations. Firstly, issues related to corporate actions that directly benefit society, such as helping to solve social problems, playing a role in society that goes beyond mere profit generation, actively collaborating in cultural and social events (music and sports, among others), or committing to improving the welfare of the communities in which they operate, are items that receive lower ratings by customers, indicating that companies should devote resources and effort to strengthening actions in this area.

Efforts within the environmental dimension were not particularly highly rated. Items such as conducting annual environmental audits, participating in environmental certifications, developing renewable resources for production processes compatible with the environment, communicating environmental practices to customers, and attempting to protect the environment, all received lower overall ratings. This phenomenon reveals a conceptual disengagement between the companies and the environmental dimension of their activities, as previous studies have shown (Forética, 2011). This finding should encourage tourism businesses to strengthen ties with their customers to ensure that they are less vulnerable to changes in their local communities and to actions by competitors.

\section{6. - Limitations and Future research}

Finally, to refine the findings of this study, some limitations of this work are outlined below. Firstly, although the proposed measurement scale uses a balanced combination of factors in each of the dimensions and provides a useful tool for measuring CSR, not all items described in the literature are used in the model presented here. As previously mentioned, for 
the initial development of the measurement scale, eighteen items of interest were selected from the marketing literature on CSR adapted from eighteen previous research studies. However, there may be other items that more fully encompass the concept of CSR and its contextual characteristics.

Secondly, the fact of obtaining our data in the accommodation subsector does not mean that the results of this research can be extrapolated to other subsectors of the tourism industry. Tentatively, the fact of using sustainable development theory, might suggest that this would be right, since this perspective has been widely applied in the field of tourism (Gladwin \& Kennelly 1995; Henderson, 2007; Kakabadse et al., 2005; Wheeler et al., 2003). Nevertheless, as mentioned in the paper, applications of CSR regarding sustainable development have mainly been theoretical to date (Panapanaan et al., 2003; Panwar et al., 2006; Van Marrewijk, 2003). Therefore, it would be necessary to replicate this research in other subsectors of the tourism industry, such as transportation, to generalize the results obtained.

Thirdly, as Churchill (1979) suggests, researchers can use the procedures described in his study with certain flexibilities and the recommended techniques can be replaced with other alternatives. The alternatives used in the current study included incorporating a panel of experts and the assessment of criterion validity with convergent validity and discriminant validity (Anderson \& Gerbing, 1988; Hung \& Petrick, 2010; Steenkamp \& Van Trijp, 1991; Turker, 2009). We consider future studies may follow the procedure suggested by this author including all the steps in order to guarantee better measures of CSR measurement scales.

Fourthly, the crosscutting nature of this research inhibits an understanding of the variations in the perceptions of the customers surveyed over time, suggesting that this research could be expanded by a longitudinal study. For example, as argued above, the difficult economic 
environment currently experienced by the tourism sector (Cizmar \& Vlahov, 2010) may affect the perceptions of consumers and their ratings of the most important aspects of CSR policies (European Commission, 2002; Strand, 1983; Ward et al., 2002). It would therefore be interesting to repeat the study once the tourism industry has recovered. Similarly, it would be interesting to examine the moderating role of certain demographic characteristics such as

gender, age or income, since the existence of differences in the perceptions of hotel customers in their assessment regarding CSR dimensions could be analyzed. In conclusion, although the results of this study show a plausible structure for the measurement of CSR, there is a clear need for further research to confirm the results. In particular, studies in different countries with other socio-cultural, political, or economic contexts would greatly benefit this field of research and stimulate further discussion and analysis of perceptions of CSR.

\section{Acknowledgments}

The authors would like to thank two anonymous reviewers for many helpful comments and suggestions.

\section{7. - References}

Adams, C. \& Zutshi, A. (2004). Corporate social responsibility: Why business should act responsibly and be accountable. Australian Accounting Review, 14(3), 31-45.

Amato, L. H., \& Amato, C. H. (2007). The effects of firm size and industry on corporate giving. Journal of Business Ethics, 72(3), 229-241.

Anderson, J. C. \& Gerbing, D. W. (1998). Structural equation modelling in practice: A review and recommended two-step approach. Psychological Bulletin, 103(3), 411-423. 
Aupperle, K., Carroll, A., \& Hatfield, J. (1985). An empirical examination of the relationship between corporate social responsibility and profitability. Academy of Management Journal, 28(2), 446-463.

Backhaus, K., Stone, B. \& Heiner, K. (2002). Exploring the relationship between corporate social performance and employer attractiveness. Business and Society, 41(3), 292-318.

Basil,D. Runte,M., Easwaramoorthy, M. \& Barr, C. (2009). Company support for employee volunteering: A national survey of companies in Canada. Journal of Business Ethics, 85, 387-399.

Bentler, P.M. \& Bonnett, D.G. (1980). Significance tests and goodness of fit in the analysis of covariance structures. Psychological Bulletin, 88, 588-606.

Bentler, P.M. (1988). Comparative fit indexes in structural models. Psychological Bulletin, 7 , 238-246.

Bentler, P.M. (1992). On the fit of models to covariances and methodology to the Bulletin. Psychological Bulletin, 112, 400-404.

Bentler, P. M. (1995). EQS structural equations program manual.Multivariate Software Encino, CA.

Berens, G., Riel, C. B. M. f., \& van Rekom, J. (2007). The CSR quality trade-off: When can corporate social responsibility and corporate ability compensate each other? Journal of Business Ethics, 74(3), 233-252.

Bigné, E., Andreu, L., Chumpitaz, R. \& Swaen, V. (2005). Percepción de la responsabilidad social corporativa: un análisis cross-cultural. Universia Business Review, 5, 14-27. 
Bigné, E., Andreu, L., Chumpitaz, R., \& Swaen, V. (2006). La influencia de la responsabilidad social corporativa en el comportamiento de compra de estudiantes universitarios. Esic Market, 6(597), 163-189.

Biloslavo, R., \& Trnavcevic, A. (2009). Web sites as tools of communication of a green company. Management Decision, 47(7), 1158-1173.

Bollen, K. A., \& Bollen, K. A. (1989). Structural equations with latent variables. Wiley New York.

Bowen, H. R. (1953). Social responsibilities of the businessman. Harper.

Bragdon, J. H. \& Marlin, J. A. (1972). Is pollution profitable? Risk Management, 19, 9-18.

Brown, T., \& Dacin, P. (1997). The company and the product: Corporate associations and consumer product responses. Journal of Marketing, 61(1), 68-84.

Campbell, J.L. (2007). Why would corporations behave in socially responsible ways? An institutional theory of corporate social responsibility. The Academy of Management Review, 32(3), 946-967.

Carroll, A.B. (1979). A three dimensional conceptual model of corporate performance. Academy of Management Review, 184, 497-505.

Carroll, A. B. (1991). The pyramid of corporate social responsibility: toward the moral management of organizational stakeholders. Business Horizons, 34(4), 39-48.

Carroll, A. B. (1999). Corporate social responsibility: Evolution of a definitional construct. Business and Society, 38(3), 268-295. 
Carroll, A. B. (2000). A commentary and an overview of key questions on corporate social performance measurement. Business \& Society, 39 (4), 466-478.

Census Bureau (2010). URL: http://www.ine.es

Churchill, G. A. (1979). A paradigm for developing better measures of marketing constructs. Journal of Marketing Research, 16(2), 64-73.

Cizmar,S. \& Vlahov,A. (2010). Crisis management in hospitality industry: Case of Croatia. An Enterprise Odyssey. International Conference Proceedings, 1576 -1592.

Clarkson, M. (1995). A stakeholder framework for analyzing and evaluating corporate social performance. Academy of Management Review, 20(1), 92-117.

Crespo, A. H. (2007). Percepción de comportamiento responsable y costes de cambio como determinantes de la lealtad hacia un servicio. Revista Española De Investigación De Marketing, 11(1), 97-118.

Davidson, W. N. \& D. L. Worrell (1990). A comparison and test of the use of accounting and stock market data in relating corporate social responsibility and financial performance. Akron Business and Economic Review, 21, 7-19.

Davis, K. (1973). The case for and against business assumption of social responsibilities. Academy of Management Journal, 16(2), 312-312.

Decker, O. S. (2004). Corporate social responsibility and structural change in financial services. Managerial Auditing Journal, 19(6), 712-728.

Dejean F. \& Gond J.P. (2004). La responsabilité sociétale des entreprises: Enjeux stratégiques et méthodologies de recherche. Finance, Contrôle et Stratégie, 7(1), 5-31. 
D'Humières P. \& Chauveau A. (2001). Les pionniers de l'entreprise responsible. Éditions d'Organisation, Paris.

DLA Piper (2010). DLA Piper 2010 Europe Hospitality Outlook Survey. Available online in:http://www.dlapiper.com/files/Publication/04bb793e-c172-4fe9b9e92281870c703c/Presentation/PublicationAttachment/d88dc113-b4e3-4cd0-8502623a4915c430/DLA_Piper_2010_European_Hospitality_Outlook_Survey.pdf

Donaldson, T., \& Dunfee, T. W. (1994). Toward a unified conception of business ethics: Integrative. Academy of Management Review, 19(2), 252-252.

European Commission. (2001). Green Paper: Promoting a European framework for corporate social responsibility. Brussels: Commission of the European Communities.

European Commission (2002). Corporate Social Responsibility: A business contribution to sustainable development. Luxembourg: European Commission Directorate General for employment and social affairs. Unit D.I, Industrial Relations and Industrial Change.

Faulkner B., Mascardo G. \& Laws, E. (2000). Tourism in the 21st Century: Lessons from experience. Continuum, London.

Focacci, A. (2011). Corporate social responsibility performance assessment by using a linear combination of key indicators. International Journal of Business Governance and Ethics, 6(2), 183-202.

Forética (2011). Informe Forética: Evolución de la responsabilidad social corporativa en las empresas en España. Available on line in: http://www.foretica.org/ 
Freedman, M., \& Jaggi, B. (1982). Pollution disclosures, pollution performance and economic performance. Omega, 10(2), 167-179.

Freeman, R. E. (1984). Strategic management: A stakeholder approach. Pitman, Boston.

Freeman, R. E. (2000). Business ethics at the millennium. Business Ethics Quarterly, 10(1), 169-180.

Friedman, M. (2007). The social responsibility of business is to increase its profits. Corporate Ethics and Corporate Governance, 32-33, 173-178.

Fullana, P., \& Ayuso, S. (2002). Turismo sostenible. Rubes.

García de los Salmones, M., Crespo, A., \& Rodríguez del Bosque, I. (2005). Influence of corporate social responsibility on loyalty and valuation of services. Journal of Business Ethics, 61(4), 369-385.

García De Los Salmones, M.M.; Rodríguez Del Bosque, I. \& Herrero, A. (2007). Percepción de comportamiento responsable y costes de cambio como determinantes de la lealtad hacia un servicio. Revista Española de Investigación de Marketing ESIC, 11(1), 97-118.

Garriga, E., \& Melé, D. (2004). Corporate social responsibility theories: Mapping the territory. Journal of Business Ethics, 53(1-2), 51-71.

Giannarakis, G., Sariannidis, N. \& Garefalakis, A. (2011). The Content of corporate social responsibility information: The case of Greek telecommunication sector. International Business Research, 4(3), 33- 45. 
Gladwin, T., Kennelly, J., \& Krause, T. (1995). Shifting paradigms for sustainable development: Implications for management theory and research. Academy of Management Review, 20(4), 874-907.

Godfrey, P. (2005). The relationship between corporate philanthropy and shareholder wealth: A risk management perspective. Academy of Management Review, 30(4), 777-798.

Gray, R., Kouhy, R. \& Lavers, S. (1995).Corporate social and environmental reporting: A review of the literature and a longitudinal study of UK disclosure. Accounting, Auditing and Accountability Journal, 8(2), 47-77.

Green Hotelier (2005). Available at: www.greenhotelier.org

Green Hotels Association (2005). Available at: www.greenhotels.com/whatare.htm

Greening, D. W., \& Turban, D. B. (2000). Corporate social performance as a competitive advantage in attracting a quality workforce. Business \& Society, 39(3), 254-280.

Griffin, J. J., \& Mahon, J. F. (1997). The corporate social performance and corporate financial performance debate. Business \& Society, 36(1), 5-31.

Grönroos, C. (1994). Marketing y Gestión de Servicios. Díaz de Santos, Madrid.

Hair, J.F.; Black, W.C.; Babin, B.J. \& Anderson, R.E. (2010). Multivariate Data Analysis, Pearson Prentice-Hall, Upper Saddle River, NJ.

Henderson, J. C. (2007). Corporate social responsibility and tourism: Hotel companies in Phuket, Thailand, after the Indian Ocean tsunami. International Journal of Hospitality Management, 26(1), 228-239. 
Holcomb, J. L., Upchurch, R. S., \& Okumus, F. (2007). Corporate social responsibility: What are top hotel companies reporting? International Journal of Contemporary Hospitality Management, 19(6), 461-475.

Hung, K., \& Petrick, J. F. (2010). Developing A Measurement Scale For Constraints To Cruising. Annals of Tourism Research, 37(1), 206-228.

Jamrozy, U. (2007). Marketing of tourism: a paradigm shift toward sustainability. International Journal of Culture, Tourism and Hospitality Research, 1(2), 117-130.

Jensen, M. C. (2002). Value maximization, stakeholder theory, and the corporate objective function. Business Ethics Quarterly, 12(2), 235-256.

Joyner, B. E., \& Payne, D. (2002). Evolution and implementation: A study of values, business ethics and corporate social responsibility. Journal of Business Ethics, 41(4), 297-311.

Kakabadse, N. K., Rozuel, C., \& Lee-Davies, L. (2005). Corporate social responsibility and stakeholder approach: a conceptual review. International Journal of Business Governance and Ethics, 1(4), 277-302.

Keim, G. D. (1978). Corporate social responsibility: An assessment of the enlightened selfinterest model. Academy of Management Review, 3(1), 32-39.

Kim, S., \& Park, H. (2011). Corporate Social Responsibility as an Organizational Attractiveness for Prospective Public Relations Practitioners. Journal of Business Ethics, 103(4), 639-653. 
Kline, R. B. (2005). Principles and practice of structural equation modeling. New York, NY: The Guilford Press.

Knowles, T., Macmillan, S., Palmer, J., Grabowski, P., \& Hashimoto, A. (1999). The development of environmental initiatives in tourism: responses from the London hotel sector. International Journal of Tourism Research, 1(4), 255-265.

Mahoney, L. S., \& Thorne, L. (2005). Corporate social responsibility and long-term compensation: Evidence from Canada. Journal of Business Ethics, 57(3), 241-253.

Maignan, I., \& Ferrell, O. C. (2000). Measuring corporate citizenship in two countries: The case of the United States and France. Journal of Business Ethics, 23(3), 283-297.

Maignan, I. \& Ferrell, O. (2001). Corporate Citizen as a marketing Instrument: Concepts, Evidence and Research Directions. European Journal of Marketing, 35 (3/4), 457-463.

Maignan, I., \& Ferrell, O. C. (2003). Nature of corporate responsibilities perspectives from American, French, and German consumers. Journal of Business Research, 56(1), 55-67.

Maignan, I., Ferrell, O. C., \& Hult, G. T. M. (1999). Corporate citizenship: Cultural antecedents and business benefits. Journal of the Academy of Marketing Science, 27(4), 455-469.

Manaktola, K., \& Jauhari, V. (2007). Exploring consumer attitude and behaviour towards green practices in the lodging industry in India. International Journal of Contemporary Hospitality Management, 19(5), 364-377. 
Marin, L., \& Ruiz, S. (2007). "I need you too!" Corporate identity attractiveness for consumers and the role of social responsibility. Journal of Business Ethics, 71(3), 245260.

McGuire, J., Sundgren, A., \& Schneeweis, T. (1988). Corporate Social-Responsibility and Firm Financial Performance. Academy of Management Journal, 31(4), 854-872.

McWilliams, A., \& Siegel, D. (2001). Corporate social responsibility: A theory of the firm perspective. Academy of Management Review, 26(1), 117-127.

Mele, D. (2002). Not only stakeholder interests. The Firm Oriented Toward the Common Good. University of Notre Dame Press. Notre Dame.

Mukherji, J., \& Mukheji, A. (2002). The relationship among knowledge, opportunity, and ethical perceptions: A cross-national investigation. Teaching Business Ethics, 6(2), 219243.

Orlitzky, M., Schmidt, F. L., \& Rynes, S. L. (2003). Corporate social and financial performance: A meta-analysis. Organization Studies, 24(3), 403-441.

Panapanaan, V., Linnanen, L., Karvonen, M., \& Phan, V. (2003). Roadmapping corporate social responsibility in Finnish companies. Journal of Business Ethics, 44(2), 133-148.

Panwar, R., Rinne, T., Hansen, E., \& Juslin, H. (2006). Corporate responsibility: Balancing economic, environmental, and social issues in the forest products industry. Forest Products Journal, 56(2), 4-12.

Persais E. (2002). L'écologie comme atout stratégique: Une validation de l'approche ressources par la méthode PLS. Revue Finance Contrôle Stratégie, 5(3), 195-230. 
Pinkston, T., \& Carroll, A. (1994). Corporate Citizenship Perspectives and Foreign DirectInvestment in the United-States. Journal of Business Ethics, 13(3), 157-169.

Preston, L. E., \& Post, J. E. (1975). Private management and public policy: The principle of public responsibility, Prentice-Hall.

Rodríguez del bosque, I., San Martín, H., Collado, J. \& García de los Salmones. M.M. (2009). A framework for tourist expectations. International Journal of Culture, Tourism and Hospitality Research, 3(2), 139-147.

Rowley, T., \& Berman, S. (2000). A brand new brand of corporate social performance. Business \& Society, 39(4), 397-418.

Sen, S., \& Bhattacharya, C. B. (2001). Does doing good always lead to doing better? Consumer reactions to corporate social responsibility. Journal of Marketing Research,38(2), 225-243.

Sethi, S. P. (1975). Dimensions of Corporate Social Performance: An Analytical Framework. California Management Review, 17(3), 58-65.

Shaw, B., \& Post, F. (1993). A moral basis for corporate philanthropy. Journal of Business Ethics, 12(10), 745-751.

Singh, J., de los Salmones Sanchez,Maria del Mar Garcia, \& Rodriguez del Bosque, I. (2008). Understanding corporate social responsibility and product perceptions in consumer markets: A cross-cultural evaluation. Journal of Business Ethics, 80(3), 597611. 
Singhapakdi, A., Kraft, K. L., Vitell, S. J., \& Rallapalli, K. C. (1995). The perceived importance of ethics and social responsibility on organizational effectiveness: A survey of marketers. Journal of the Academy of Marketing Science, 23(1), 49-56.

Sotorrío, L. L., \& Sánchez, J. L. F. (2010). Corporate social reporting for different audiences: the case of multinational corporations in Spain. Corporate Social Responsibility and Environmental Management, 17(5), 272-283.

Spencer, B., \& Taylor, G. (1987). A within and between Analysis of the Relationship between Corporate Social-Responsibility and Financial Performance. Akron Business and Economic Review, 18(3), 7-18.

Stanwick, P., \& Stanwick, S. (1998). The relationship between corporate social performance, and organizational size, financial performance, and environmental performance: An empirical examination. Journal of Business Ethics, 17(2), 195-204.

Steenkamp, J. B. \& van Trijp, H. C. M. (1991). The use of LISREL in validating marketing constructs. International Journal of Research in Marketing, 8(4), 283-299.

Strand, R. (1983). A systems paradigm of organizational adaptations to the social environment. Academy of Management Review, 8(1), 90-96.

Swaen, V., Chumpitaz, R., Bigné, E., \& Andreu, L. (2003). Being a socially responsible company: What does it mean for european young consumers? Paper presented at 32nd European Marketing Academy Conference. Glasgow,University of Strathclyde, UK.

Swaen, V. \& Chumpitaz, R. (2008). Impact of corporate social responsibility on consumer trust. Recherche et Applications en Marketing, 23(4), 7-33. 
Szwajkowski, E. \& Figlewicz, R. (2011). Evaluating corporate performance: A comparison of the fortune reputation survey and the Socrates Social Rating database. Journal of Managerial Issues, 11(2), 137-145.

Thomas, A., \& Simerly, R. (1995). Internal determinants of corporate social performance: The role of top managers. Best Papers Proceedings Fifty Fifth Annual Meeting of the Academy of Management, , 411-415.

Timur, S., \& Getz, D. (2009). Sustainable tourism development: How do destination stakeholders perceive sustainable urban tourism? Sustainable Development, 17(4), 220232.

Tipuric,D. \& Lovrincevic, M. (2011). Stakeholder orientation and firm performance: Value generating strategy or sophisticated entrenchment strategy?: Empirical evidence from Croatia. The Business Review, 17(2), 220 -229.

Tourism Studies Institute (2001). Tourism Indicators. Available on line in:http://www.iet.tourspain.es/paginas/home.aspx?idioma=es-ES

Trespalacios, J. A., Vázquez, R., \& Bello, L. (2005). Investigación de Mercados. Thomson, Madrid.

Truscott, R. A., Bartlett, J. L., \& Tywoniak, S. A. (2009). The reputation of the corporate social responsibility industry in Australia. Australasian Marketing Journal (AMJ), 17(2), 84-91.

Turker, D. (2009). Measuring corporate social responsibility: A scale development study. Journal of Business Ethics, 85(4), 411-427. 
Ullman, J.D. (1996). Structural Equation Modelling. In Uriel, E. \& Aldás, J. (Eds.), Análisis Multivariante Aplicado, Thomson.

Uriel, E., \& Aldás, J. (2005). Análisis multivariado aplicado. Thomson, Madrid.

van Marrewijk, M. (2003). Concepts and definitions of CSR and corporate sustainability: Between agency and communion. Journal of Business Ethics, 44(2), 95-105.

Varadarajan, P., \& Menon, A. (1988). Cause Related Marketing: A coalignment of marketing strategy and corporate philanthropy. Journal of Marketing, 52(3), 58-74.

Vidal, N. G., \& Kozak, R. A. (2008). Corporate responsibility practices in the forestry sector. Journal of Corporate Citizenship, 31, 59-75.

Vitell, S. J., Ramos, E., \& Nishihara, C. M. (2010). The role of ethics and social responsibility in organizational success: A spanish perspective. Journal of Business Ethics, 91(4), 467-483.

Votaw, D. (1972). Genius becomes rare: A confiment on the doctrine of social responsibility. California Management Review, 15(2), 25-32.

Waddock, S., \& Graves, S. (1997). The corporate social performance: Financial performance link. Strategic Management Journal, 18(4), 303-319.

Walker, M., Heere, B., Parent, M. M., \& Drane, D. (2010). Social responsibility and the Olympic Games: The mediating role of consumer attributions. Journal of Business Ethics, 95(4), 659-680.

Walsh, J., Weber, K., \& Margolis, J. (2003). Social issues and management: Our lost cause found. Journal of Management, 29(6), 859-881. 
Ward,H., Borregaard, N. \& Kapelus, P. (2002). Corporate citizenship: Revisiting the relationship between business, good governance and sustainable development. International Institute for Environment and Development. Available on line in: http://pubs.iied.org/pdfs/11034IIED.pdf

Wheeler, D., Colbert, B., \& Freeman, R. E. (2003). Focusing on value: Reconciling corporate social responsibility, sustainability and a stakeholder approach in a network world. Journal of General Management, 28(3), 1-28.

Whitehouse, L. (2006). Corporate social responsibility: Views from the frontline. Journal of Business Ethics, 63(3), 279-296.

Wolfe, R. \& Aupperle K. (1991). Introduction to Corporate Social Performance: Methods for Evaluating an Elusive Construct, in Post, J.E (Eds.), Research in Corporate Social Performance and Policy, 265-268.

Wood, D., \& Logsdon, J. (2009). Business citizenship: From individuals to organizations. Business Ethics Quarterly, 3, 59-94.

Wood, D. (1991). Corporate social performance revisited. Academy of Management Review, 16(4), 691-718.

World Tourism Organization (2004). Statements by the World Tourism Organization in relation to sustainable tourism development: Concepts and definitions. Available on line in: http://www.unwto.org/espanol/frameset/frame_sustainable.html

World Tourism Organisation (1997). Yearbook of Tourism Statistics, vol. 1. Madrid: WTO. 
World Travel and Tourism Council (2000). Travel \& Tourism Satellite Accounting Research

Estimates and Forecasts. Available on line in: http://www.wttc.org

World Travel Organization (2011). Tourism Highlights. Available on line in

http://mkt.unwto.org/en/content/tourism-highlights

Tables and Figures

TABLE 1. Existing methods for measuring CSR

\begin{tabular}{|c|c|c|}
\hline Method & Limitation & Research \\
\hline Reputation Indices & $\begin{array}{l}\text { Items not based on } \\
\text { theoretical arguments }\end{array}$ & $\begin{array}{l}\text { McGuire, Sundgren \& Schneeweis (1988); } \\
\text { Orlitzky, Schmidt \& Rynes (2003); } \\
\text { Sotorrio \& Sánchez (2010);Spencer \& Taylor } \\
\text { (1987); Thomas \& Simerly (1995); Waddock } \\
\text { \&Graves (1997); }\end{array}$ \\
\hline Databases & $\begin{array}{l}\text { Narrow evaluation } \\
\text { range }\end{array}$ & $\begin{array}{l}\text { Amato \& Amato (2007); Mahoney \& Thorne } \\
\text { (2005); Szwajkowski \& Figlewicz (1999) }\end{array}$ \\
\hline Indicators & $\begin{array}{l}\text { Problems when } \\
\text { encompassing the entire } \\
\text { structure of CSR }\end{array}$ & $\begin{array}{c}\text { Bragdon \& Marlin (1979); Davidson \& Worrell, } \\
\text { (1990); Focacci (2011); Freedman \& Jaggi (1982); } \\
\text { Giannarakis, Sariannidis \& Garefalakis (2011) } \\
\text { Turban \& Greening, (1996) }\end{array}$ \\
\hline $\begin{array}{l}\text { Content analysis of } \\
\text { publications }\end{array}$ & $\begin{array}{l}\text { Reliability of the } \\
\text { companies }\end{array}$ & $\begin{array}{l}\text { Biloslavo \& Trnavcevic (2009); Giannarakis, } \\
\text { Sariannidis \& Garefalakis (2011); Gray, Kouhy \& } \\
\text { Lavers (1995); Holcomb, Upchurch \& Okumus } \\
\text { (2007); McGuire, Sundgren \& Schneeweis }\end{array}$ \\
\hline $\begin{array}{c}\text { Surveys of organizational } \\
\text { members }\end{array}$ & $\begin{array}{l}\text { Impossibility of } \\
\text { estimating the socially } \\
\text { responsible practices } \\
\text { adopted by companies } \\
\text { as a whole }\end{array}$ & $\begin{array}{c}\text { Aupperle ,Carroll \& Hatfield (1985); Basil, Runte, } \\
\text { Easwaramoorthy \& Barr (2009); Pinkston \& } \\
\text { Carroll (1994); Singhapakdi, Kraft, Vitell \& } \\
\text { Rallapalli (1995); Tipuric \& Lovrincevic (2011); } \\
\text { Vitell, Ramos \& Nishihara (2010) }\end{array}$ \\
\hline
\end{tabular}

Source: prepared by the authors based on Maignan and Ferrell (2000) and Turker (2009).

TABLE 2. Quantitative research technical record

\begin{tabular}{ll}
\hline \hline Universe & Hotel clients over 18 years of age \\
\hline Scope & Spain (The Autonomous Community of Cantabria) \\
\hline Date of fieldwork & April 2011 \\
\hline Sample & 1924 valid questionnaires \\
\hline Sampling procedure & Quota sampling according to the criteria of 1) sex and 2) age \\
\hline Processing of data & PASW v. 18.0, EQS v. 6.1 \\
\hline \hline
\end{tabular}


TABLE 3. Sample profile

\begin{tabular}{lcclcc}
\hline & N & \% & & N & \% \\
\hline Gender: & & & Age: & 193 & 10 \\
Male & 959 & 49.8 & From 18 to 24 years & 382 & 19.9 \\
Female & 962 & 50.2 & From 25 to 34 years & 362 & 18.8 \\
& & & From 35 to 44 years & 364 & 18.9 \\
& & & From 45 to 54 years & 265 & 13.8 \\
& & & From 55 to 64 years & 357 & 18.6 \\
& & & Over 65 Years & & \\
Occupation: & & & Education: & 156 & 8.1 \\
Student & 272 & 14.1 & No education & 440 & 22.9 \\
Self-employed & 263 & 13.7 & Basic/Elementary/Secondary & 573 & 29.8 \\
Worker & 758 & 39.4 & Baccalaureate/FP/COU/BUP & 390 & 20.3 \\
Retired/Pensioner & 336 & 17.5 & Associate degree & 363 & 18.9 \\
\hline Unemployed & 107 & 5.6 & Higher university & & \\
\hline
\end{tabular}

Source: National Statistics Institute - INE (data from January 1, 2011).

Table 4. Procedure for developing instrument measures.

\begin{tabular}{|c|c|c|}
\hline $\begin{array}{c}\text { Procedures for developing } \\
\text { better measures suggested by } \\
\text { Churchill (1979) }\end{array}$ & $\begin{array}{l}\text { Techniques recommended by } \\
\text { Churchill (1979) }\end{array}$ & $\begin{array}{l}\text { Techniques used in } \\
\text { this study }\end{array}$ \\
\hline $\begin{array}{l}\text { 1. Specify domain of construct } \\
\text { 2. Generate sample of items }\end{array}$ & $\begin{array}{l}\text { Literature search } \\
\text { Literature search } \\
\text { Experience survey } \\
\text { Insight-stimulating examples } \\
\text { Critical incidents } \\
\text { Focus groups }\end{array}$ & $\begin{array}{l}\text { Literature search } \\
\text { Literature search } \\
\text { Panel of experts }\end{array}$ \\
\hline 3. Collect data & & Pilot study \\
\hline $\begin{array}{l}\text { 4. Purify measure } \\
\text { 5. Collect data }\end{array}$ & $\begin{array}{l}\text { Coefficient alpha } \\
\text { Factor analysis }\end{array}$ & $\begin{array}{l}\text { Coefficient alpha } \\
\text { Factor analysis } \\
\text { Personal survey }\end{array}$ \\
\hline 6. Assess reliability & $\begin{array}{l}\text { Coefficient alpha } \\
\text { Split-half reliability }\end{array}$ & Composite reliability \\
\hline 7. Assess validity & $\begin{array}{l}\text { Multitrait-multimethod matrix } \\
\text { Criterion validity }\end{array}$ & $\begin{array}{l}\text { Convergent validity } \\
\text { Discriminant validity }\end{array}$ \\
\hline 8. Develop norms & $\begin{array}{l}\text { Average and other statistics } \\
\text { summarizing distribution of } \\
\text { scores }\end{array}$ & $\begin{array}{l}\text { Means } \\
\text { Standard deviations }\end{array}$ \\
\hline
\end{tabular}


Table 5. Experts participating in the panel

\begin{tabular}{ll}
\hline \hline \multicolumn{1}{c}{ Name } & \multicolumn{1}{c}{ Position held } \\
\hline \hline Sebastián Escarrer & Non Executive Vice Chairman Meliá Hotels International \\
\hline Esther Trujillo & $\begin{array}{l}\text { SVP Institutional and Corporate Diplomacy Office Meliá Hotels } \\
\text { International }\end{array}$ \\
\hline Lourdes Ripoll & Strategic Planning Group Director Meliá Hotels International \\
\hline Carmen Molano & Sustainable Development Department Director Meliá Hotels International \\
\hline Gonzalo Echevarría & Meliá Palas Atenea General Manager \\
\hline Inmaculada Palencia & Gran Meliá Fénix General Manager \\
\hline \hline
\end{tabular}

Table 6. Discriminant validity

\begin{tabular}{lcc}
\hline \hline Dimensions & Correlation & Confidence interval \\
\hline \hline Economy - Society & 0.123 & $(0.105-0.221)$ \\
Economy - Environment & 0.168 & $(0.070-0.186)$ \\
Society - Environment & 0.637 & $(0.621-0.737)$ \\
\hline \hline
\end{tabular}

TABLE 7. First-order confirmatory factor analysis of the dimensions of corporate social responsibility

\begin{tabular}{|c|c|c|c|c|c|c|}
\hline $\begin{array}{c}\text { Latent } \\
\text { variable }\end{array}$ & $\begin{array}{c}\text { Measured } \\
\text { variable }\end{array}$ & $\begin{array}{c}\text { Standardized } \\
\text { Lambda }\end{array}$ & $\mathbf{R 2}$ & $\begin{array}{c}\text { Cronbach`s } \\
\alpha\end{array}$ & AVE & Goodness of fit \\
\hline \multirow{4}{*}{ Economy } & 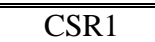 & 0.782 & 0.612 & & & \multirow{5}{*}{$\begin{array}{c}\text { S-B } \chi 2(113 \mathrm{gl}) \\
1185.51 \\
(\mathrm{p}=0.000)\end{array}$} \\
\hline & CSR2 & 0.858 & 0.736 & & & \\
\hline & CSR3 & 0.834 & 0.696 & 0.896 & 0.683 & \\
\hline & CSR4 & 0.829 & 0.687 & & & \\
\hline \multirow{6}{*}{ Society } & CSR5 & 0.713 & 0.508 & \multirow{6}{*}{0.865} & \multirow{6}{*}{0.517} & \\
\hline & CSR6 & 0.709 & 0.504 & & & \\
\hline & CSR7 & 0.776 & 0.602 & & & NFI \\
\hline & CSR8 & 0.649 & 0.421 & & & 0.923 \\
\hline & CSR9 & 0.699 & 0.489 & & & \\
\hline & CSR10 & 0.761 & 0.580 & & & NNFI 0.915 \\
\hline \multirow{7}{*}{ Environment } & CSR11 & 0.742 & 0.550 & \multirow{7}{*}{0.984} & \multirow{7}{*}{0.551} & \multirow{3}{*}{$\begin{array}{c}\text { CFI } \\
0.930\end{array}$} \\
\hline & CSR12 & 0.753 & 0.567 & & & \\
\hline & CSR13 & 0.726 & 0.526 & & & \\
\hline & CSR14 & 0.722 & 0.521 & & & IFI \\
\hline & CSR15 & 0.796 & 0.634 & & & 0.930 \\
\hline & CSR16 & 0.783 & 0.613 & & & \\
\hline & CSR17 & 0.771 & 0.594 & & & \\
\hline
\end{tabular}

FIGURE 1.Second-order confirmatory factor analysis of the dimensions of corporate social responsibility 


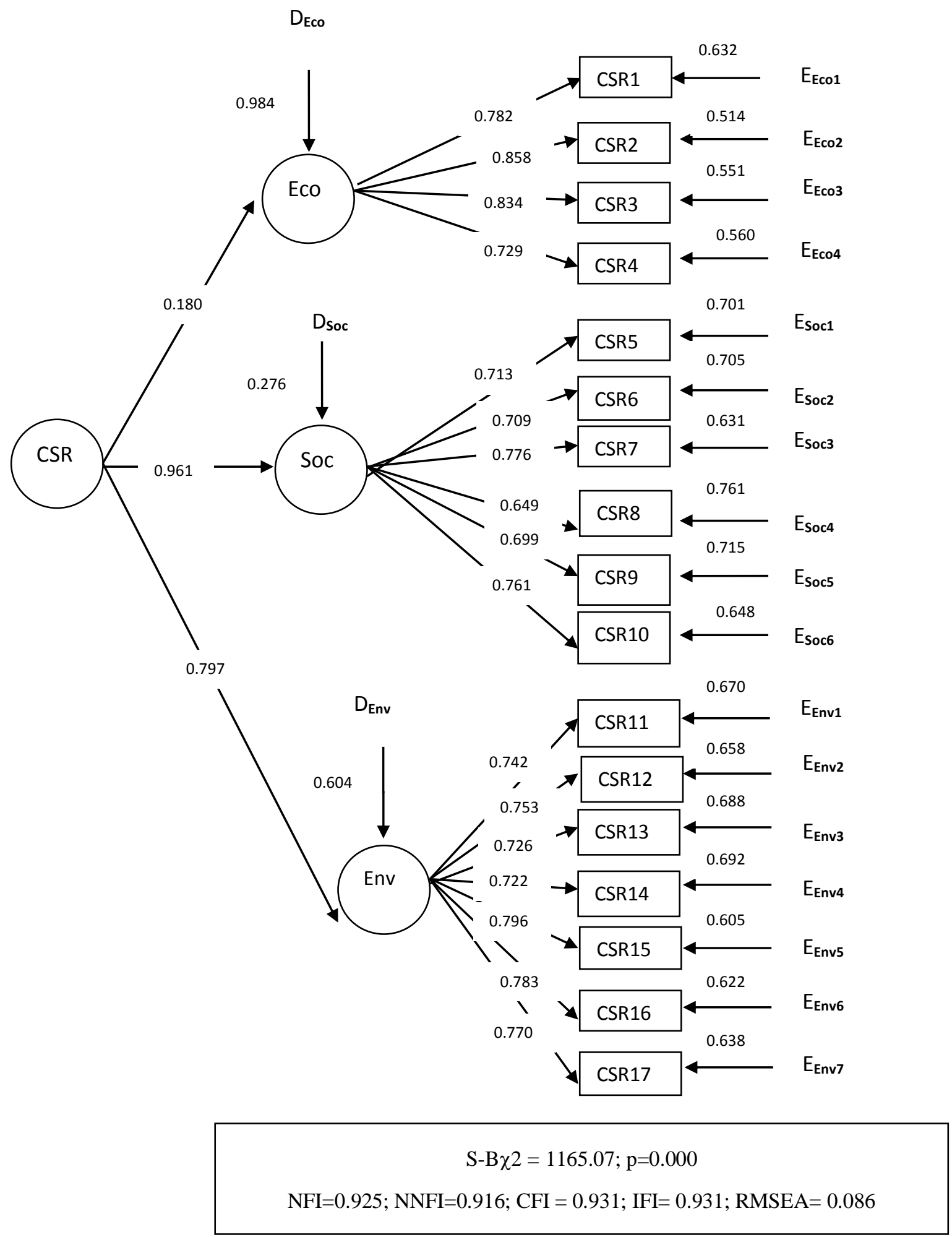




\section{TABLE 8. Final CSR measurement scale}

\begin{tabular}{|c|c|c|c|}
\hline Ident. & Dimension & Item & References \\
\hline \multicolumn{4}{|c|}{ I think that this company... } \\
\hline CSR1 & Economic & $\begin{array}{l}\text { Obtains the greatest possible } \\
\text { profits }\end{array}$ & $\begin{array}{l}\text { Bigné, Andreu, Chumpitaz \& Swaen (2005); García de los } \\
\text { Salmones, Herrero \& Rodríguez Del Bosque (2005); Maignan } \\
\text { (2001); Maignan, Ferrell \& Hult (1999) }\end{array}$ \\
\hline CSR2 & Economic & $\begin{array}{l}\text { Tries to achieve long-term } \\
\text { success }\end{array}$ & $\begin{array}{l}\text { García de los Salmones ,Herrero \& Rodríguez Del Bosque (2005); } \\
\text { Maignan (2001) }\end{array}$ \\
\hline CSR3 & Economic & $\begin{array}{l}\text { Improves its economic } \\
\text { performance }\end{array}$ & $\begin{array}{l}\text { García de los Salmones, Herrero \& Rodríguez Del Bosque (2005); } \\
\text { Maignan (2001) }\end{array}$ \\
\hline CSR4 & Economic & $\begin{array}{l}\text { Ensures its survival and } \\
\text { success in the long run }\end{array}$ & García de los Salmones, Herrero \& Rodríguez Del Bosque (2005) \\
\hline CSR5 & Social & $\begin{array}{l}\text { Is committed to improving } \\
\text { the welfare of the } \\
\text { communities in which it } \\
\text { operates }\end{array}$ & $\begin{array}{l}\text { Bigné, Andreu, Chumpitaz \& Swaen (2005); Marín \& Ruiz } \\
\text { (2007); García de los Salmones, Herrero \& Rodríguez Del Bosque } \\
\text { (2005); García de los Salmones, Rodríguez Del Bosque \& Herrero } \\
\text { (2007); Singh, García De Los Salmones \& Rodríguez Del Bosque } \\
\text { (2008) }\end{array}$ \\
\hline CSR6 & Social & $\begin{array}{l}\text { Actively participates in } \\
\text { social and cultural events } \\
\text { (music, sports, etc.) }\end{array}$ & $\begin{array}{l}\text { García de los Salmones, Rodríguez Del Bosque \& Herrero (2007); } \\
\text { Maignan, Ferrell \& Hult (1999); Singh, García De Los Salmones \& } \\
\text { Rodríguez Del Bosque (2008) }\end{array}$ \\
\hline CSR7 & Social & $\begin{array}{l}\text { Plays a role in society that } \\
\text { goes beyond mere profit } \\
\text { generation }\end{array}$ & $\begin{array}{l}\text { Berens, Riel and van Rekom . (2007); Maignan (2001) ;Sen \& } \\
\text { Bhattacharya (2001) }\end{array}$ \\
\hline
\end{tabular}

Provides a fair treatment of employees (without

CSR8 Social discrimination and abuse, regardless of gender, race, origin or religion)

Bigné, Andreu, Chumpitaz \& Swaen (2005); Maignan, Ferrell \&

Hult (1999)

\begin{tabular}{ccc}
\hline CSR9 & Social & $\begin{array}{c}\text { Provides training and } \\
\text { promotion opportunities for } \\
\text { employees }\end{array}$ \\
\hline CSR10 & Social & $\begin{array}{c}\text { Helps to solve social } \\
\text { problems }\end{array}$ \\
\hline
\end{tabular}

Bigné, Andreu, Chumpitaz \& Swaen (2005)

Maignan (2001)

Bigné, Andreu, Chumpitaz \& Swaen (2005); Brown \& Dacin

CSR11 Environmental Protects the environment (1997); García de los Salmones, Herrero \& Rodríguez Del Bosque (2005); García de los Salmones, Rodríguez Del Bosque \& Herrero (2007); Marín \& Ruiz (2007); Singh, García De Los Salmones \& Rodríguez Del Bosque (2008)

\begin{tabular}{clcl}
\hline CSR12 & Environmental & $\begin{array}{c}\text { Reduces its consumption of } \\
\text { natural resources }\end{array}$ & $\begin{array}{l}\text { Bigné, Andreu, Chumpitaz \& Swaen (2005); Knowles, Macmillan, } \\
\text { Palmer, Grabowski \& Hashimoto (1999);Manaktola \& Jauhari } \\
(2007)\end{array}$ \\
\hline CSR13 & Environmental & Recycles & $\begin{array}{l}\text { Knowles, Macmillan, Palmer, Grabowski \& Hashimoto(1999); } \\
\text { Manaktola \& Jauhari (2007) }\end{array}$ \\
\hline CSR14 & Environmental & $\begin{array}{c}\text { Communicates to its } \\
\text { customers its environmental } \\
\text { practices }\end{array}$ & $\begin{array}{l}\text { Bigné, Andreu, Chumpitaz \& Swaen (2005); Knowles ,Macmillan, } \\
\text { Palmer, Grabowski \& Hashimot (1999); Manaktola \& Jauhari } \\
(2007)\end{array}$ \\
\hline CSR15 & Environmental & $\begin{array}{c}\text { Exploits renewable energy } \\
\text { in a productive process } \\
\text { compatible with the } \\
\text { environment }\end{array}$ & $\begin{array}{l}\text { Bigné, Andreu, Chumpitaz \& Swaen (2005); Knowles, Macmillan, } \\
\text { Palmer, Grabowski \& Hashimoto (1999); Manaktola \& Jauhari } \\
(2007)\end{array}$ \\
\hline
\end{tabular}

CSR16 Environmental Conducts annual environmental audits 
TABLE 9. Assessment of the performance of the hotels analyzed in each factor of the CSR measurement scale

\begin{tabular}{cccccc}
\hline \hline Ident. & Mean & Ident. & Mean & Ident. & Mean \\
\hline \hline CSR 4 & 5.80 & CSR 9 & 4.39 & CSR 15 & 3.90 \\
\hline CSR 2 & 5.69 & CSR 12 & 4.18 & CSR 17 & 3.85 \\
\hline CSR 1 & 5.67 & CSR 11 & 4.15 & CSR 7 & 3.78 \\
\hline CSR 3 & 5.57 & CSR 5 & 4.08 & CSR 10 & 3.74 \\
\hline CSR 8 & 4.68 & CSR 14 & 3.98 & CSR 16 & 3.69 \\
\hline CSR 13 & 4.48 & CSR 6 & 3.96 & & \\
\hline
\end{tabular}

TABLE 10. Means test of the ratings of the CSR dimensions

\begin{tabular}{lccc}
\hline \hline Dimension & Mean & Std. deviation & Signification \\
\hline \hline Economic & 5.6822 & 1.12259 & 0.000 \\
Social & 4.1034 & 1.10474 & 0.000 \\
Environment & 4.0335 & 1.18553 & 0.001 \\
\hline \hline
\end{tabular}

